\title{
Transnistria: a paradise for vested interests
}

\section{Changing regional geography}

Moldova is the only country in the European hemisphere of the ex-USSR that experienced large-scale armed conflict on its territory, in 1992, which ended with more than a thousand human casualties. This saw considerable civilian destruction and effectively a full separation of the eastern districts along the left bank of the Dniester river and the city of Bender on the right bank. Nevertheless, many authors, diplomats and military and various other officials have insisted that this conflict would be very easy to resolve. Apart from the other conflicts with which it is usually compared, it has not been ethnicity that led to conflicts and violence breaking out in Transnistria, but a combination of economic fears and military intervention, coupled with an active manipulation of the post-imperial syndrome of the 'siege fortress', which has secured almost unlimited military, political and economic support for the separatist regime from the Russian Federation.

Moldova is a formal democracy, with elections held regularly and power changing hands, but Transnistria has organised only mock popular consultations, such that the same leaders that went to war in 1992 have prevailed in the past decade of domestic turmoil. That was certainly due to the tributes paid by local elites to their ties with Moscow which, at least until very recently, wanted no change in the existing status quo in the region. Regular elections were intended by the Moldovan government for the separatist region, but they could be organised only in a tiny strip of Moldovan villages located on the left bank, being refused by the separatist regime, and not in the major cities of the region: Tiraspol, Bender, Rabnita and Dubasari. Those who dared to vote or compete in the elections conducted by the constitutional authorities of Moldova faced the threat of being arrested.

There was little direct threat to renew hostilities between the 'parts in conflict', but the Russian peacekeepers clearly supported the Tiraspol regime in strengthening its military capabilities and creating a 'Transnistrian Army' which outnumbers the Moldovan Army. Against the provisions of the Ceasefire Agreement, signed in July 1992 by Russia and Moldova, the Russian Federation has unilaterally reduced its peacekeepers from 2400 to 1200 in 1994, with the aim of allowing the Tiraspol military to claim a greater participation in the peacekeeping forces and thus changing the balance of forces. Later on, in November 1994, the number of peacekeepers was reduced to 630 people while the Transnistrian military raised its presence to 850 personnel; Moldova reduced its number to 420. Moreover, it has been quite successful in regaining control over the security zones formally controlled by the Unified Control Commission (CUC), whose mission would have been precisely to avoid any steps that would provide strategic military advantages to any of the parts in con- 
flict. ${ }^{1}$ After more than ten years of totally futile mediation, in which Russia practically excluded the west from any tangible role in the process of conflict regulation, the separatist regime is still alive and very keen to infuse other regions with its endemic influences.

\section{Characteristics of the regional economy}

Most of the industrial infrastructure of Soviet Moldova was located on the eastern bank of the Dniester, which is now controlled by the Transnistrian regime. One of the last bastions of Soviet-style rhetoric, the territory has nonetheless privatised some of its industrial enterprises. Not surprisingly, the dispute between Tiraspol and Chișinău also covers the issue of control of the economic assets of Transnistria. Moldova has passed a law stating that any privatisation on the territory of Moldova (including Transnistria) must be approved by the Moldovan parliament; nevertheless, the Transnistrian leadership began its "privatisation with a human face' 2 of what had been Moldovan state property in the region. However, the authors of a report produced by The Bar Association of the City of New York ${ }^{3}$ on Transnistria have questioned, among other aspects of the conflict, the right of the Transnistrian regime to privatise property in its area of effective control, as well as the possible consequences of such privatisation decisions in the event of the possible future re-integration of the two parts of Moldova. The authors of the report mention that:

Since 2002, the Transnistrian authorities have sold 37 major assets for $\$ 51.5$ million... Many of the deals were 'sweetheart' deals for those close to President Igor Smirnov and his entourage.

The privatisation process started as early as 2000 , when the Transnistrian authorities started to prepare the enterprises of the region for privatisation and, of course, the main cash beneficiaries of that could not be other than Russian oligarchs. Despite official warnings that the Moldovan authorities would not officially recognise any sort of privatisation deals in Transnistria outside of the legal/constitutional space of Chișinău, gas debts started to be accumulated while Russian giants used the debts to take over important industries in Transnistria. In 2003, the Tiraspol administration re-

1 Under the shelter of the Russian peacekeepers, Transnistria introduced over 3500 personnel from various paramilitary units, border troops and Cossacks. Just as the Ingury River in Georgia became a war demarcation line between government and separatist forces, so in Moldova did the Dniestr River become a military line but with the exceptional difference that the Moldovan constitutional authorities still maintained effective control over seven villages on the left bank of the River while the secessionist regime of Tiraspol expanded its influence over the right bank city of Bender, the third largest in Moldova. Thus, contrary to the propaganda highlighting peacekeeping operations in Transnistria as a successful case, it led neither to the regulation of the conflict nor to the de-militarisation of forces hostile to peace.

2 '... The country decided to make human values the main priority of the privatisation process. ... The privatisation programme for 2006 included approximately 130 stateowned companies.' http://pridnestrovie.net/privatization.html

3 Thawing a Frozen Conflict: Legal Aspects of the Separatist Crisis in Moldova A report from the Association of the Bar of the City of New York. 
ceived loans amounting to $\$ 150 \mathrm{~m}$ in exchange for some major defence industrial units. ${ }^{4}$ Most of these enterprises were suspected by the Moldovan authorities of producing and selling arms. Earlier, the Military-Industrial Courier posted a list of Transnistrian defence industries put up for sale as well as their main production items, their location and structure of ownership.

In June 2005, the 'Ministry of Economy' of Transnistria released data stating that, in the year to date, ten major assets were 'privatised' for a price of $\$ 4.8 \mathrm{~m}$. This included the Tiraspol bread bakery $(\$ 1.49 \mathrm{~m})$, the Tiraspol bread-product integrated works $(\$ 1.29 \mathrm{~m})$ and the Odema textile factory $(\$ 1.29 \mathrm{~m})$. The bread-making assets were purchased by the Sheriff company. ${ }^{5}$

Official communiqués claim that the region saw 'marked improvement in the main macroeconomic indicators from 2000 to 2005,' when 'GDP increased 209.6\% ... and per capita GDP experienced an increase of $223.0 \%,{ }^{6}$, while even some foreign researchers acknowledge that:

Transnistria has achieved a relatively high degree of self-sufficiency during its nearly eighteen years of self-proclaimed independence. ${ }^{7}$

Nevertheless, the economic viability of the Transnistrian regime remains a chimera for several reasons.

First, it is heavily based on the 'unofficial' shadow economy. According to some research studies, the annual turnover of Sheriff, controlled by the President of the self-proclaimed republic, is around $\$ 2 \mathrm{bn}$, i.e. five times bigger than the budget of Moldova and 25 times bigger than that of the 'Transnistrian Moldovan Republic' $(\$ 85 \mathrm{~m}) .{ }^{8}$ The sources of such wealth include money laundering, smuggling and trafficking: it is contraband and the smuggling of weapons, alcohol, oil, drugs, pharmaceuticals, tobacco and other goods on the Tiraspol-Odessa line that are bringing these $\$ 2$ bn a year to Smirnov's regime.

The 'official' economy, on the other hand, has avoided collapse because of massive external subsidies. Russia has made the Transnistrian economy viable by providing energy at much lower rates compared to what is provided to Moldova. Gazprom is charging Transnistria $\$ 60$ per thousand cubic meters (three times less than the price Moldovan customers are charged), while the Transnistrian unpaid debt for Russian gas is $\$ 1.3 \mathrm{bn}$, twice as big as Moldova's debt. ${ }^{9}$ This gives Transnistrian manufacturers an artificially-created market competitiveness as they can produce and sell goods more cheaply. For instance, the Rabnita steel factory has received gas for only $\$ 30$

4 «Киевские ведомости»; Новости-Молдова.

5 Thawing a Frozen Conflict: Legal Aspects of the Separatist Crisis in Moldova: A report from the Association of the Bar of the City of New York.

6 http://pridnestrovie.net

7 Mihály Borsi (2007) Transnistria - an unrecognised country within Moldova ICEG European Center News of the Month, December (re-printed in this edition of the SEER).

8 Ceslav Ciobanu (2008) Frozen and Forgotten Conflicts in the Post-Soviet States: Genesis, Political Economy and Prospects for Solution United States Institute of Peace: Virginia State University, Richmond.

9 Infotag 26 March 2007; Nezavisimaya Moldova 30 January 2007. 
per 1000 cubic meters and this has made it quite a profitable factory for the last decade, being also the main contributor to the budget of the region (60\% of its income). The same is true for the cement industry and other industrial plants located in Tiraspol, and also for the population of urban settlements in the breakaway region which have simply not paid their utilities bills for the long years since subsequent to the Soviet dissolution.

Gazprom has not sought the gas debts of more than one billion dollars, nor have the Transnistrian leaders admitted the obligations to paying the above-mentioned debts. Igor Smirnov commented recently that:

Transnistria has no legal [gas] debt, because there is no contract signed with 'Gazprom'.

According to Smirnov, the contract was signed between 'Gazprom' and 'Moldova-gaz', in which Transnistria had a share of $14.7 \%$ but from which it later withdrew. ${ }^{10}$

The Transnistrian regime states that:

Pridnestrovie has a stronger, more open and prosperous free market economy than Moldova, ${ }^{11}$

but, looking at the facts, one can realise that no credit can be taken by the region's authorities for its 'economic growth'. At the end of 2007, Gazprom announced that the debts accumulated by Transnistria alone reached $\$ 1.8 \mathrm{bn},{ }^{12}$ and that the debts fall under the responsibility of Moldova for repayment, with penalties already imposed on Moldova. Apart from that, since 1994, Moldova was one of the highest payers for gas delivered by Russia compared to other CIS and Baltic states. So, whereas by 1999 Moldova was paying $\$ 120$ (compared with $\$ 30$ in Belarus, $\$ 50$ in Ukraine and $\$ 60$ in Georgia), by 2000 Moldova was already paying $\$ 150-\$ 160$ along with Ukraine, compared to $\$ 120-\$ 125$ per thousand cubic meters for the Baltic countries and $\$ 110$ for Georgia and Armenia. ${ }^{13}$ Since 2007, Moldova has been paying $\$ 190$ and, since January 2008, \$210, outscoring Ukraine which has remained at $\$ 190$ as well as some of the Baltic states.

Nevertheless, with the growing confrontations with Ukraine on gas transit, and the strategic aim of influencing the gas distribution policies of Europe, Gazprom suddenly changed its policy towards Transnistria. Since 2006, Tiraspol has been twice warned officially by Gazprom that it will be cut off from gas supplies if the debts are not paid. In February 2008, Tiraspol officially demanded that Gazprom postpone the price rises on the grounds that Transnistria is still 'a zone of very special interest for Russia'. ${ }^{14}$ Igor Smirnov stated that the region's industries cannot survive if they are:

10 «Газпром» передал Приеднестровье Алишеру Усманову. Президент Смирнов отказывается платить новому кредтору Nezavisimaya gazeta 23 March 2007.

11 http://pridnestrovie.net.

12 Infotag 16 March 2008.

13 www.reporter.md 1 December 2005.

14 AP FLUX Chișinău, 6 February 2008. 
Forced to pay $\$ 190$ per 1000 cubic meters and, if this is unacceptable to Gazprom, the whole region will be lost.

Transnistrian officials claim that they will be able to pay $100 \%$ of the bills for the gas exported by Gazprom only in $2012 .{ }^{15}$ On that basis, Chișinău has tried hard to negotiate with Moscow a differentiation in gas payments, receiving in return only vague assurances that deadlock will be avoided. The solutions are not easy, even for Gazprom, above all due to $12 \%$ of the gas exported by Russia crossing Moldova, while another burden is clearly related to the political lobby in Moscow on behalf of the Transnistrian separatists. Cheap gas and political support is still behind the survival of the Transnistrian regime.

Another factor that has maintained some of the industrial complex of Transnistria alive is the offshore statute that has helped local oligarchs to export their goods almost without restriction to the neighbouring Ukraine and Moldova, without regard to the trespassing of the borders.

Moldova is also subject to the various restrictive trade policies of Russia - traditionally its major trading partner. In 2005, Russia banned on several occasions the import of goods from Moldova: in April, a ban on meat imports was imposed, the official reason being concerns that the meat was in fact, re-exported and not domestically produced; in May, it banned the import of Moldovan fruits and vegetables, stating that Moldovan fruits and vegetables did not meet Russian standards; and, in September, Russia's Federal Customs Service stopped releasing documentary excise stamps to producers of Moldovan spirits and wines.

The economic impact of these bans are hard to under-estimate: for the wines industry alone, according to the estimates of the Moldova-Vin export agency, the loss in sales was over $\$ 180 \mathrm{~m}$ between March 2006 and January 2007. The indirect effects on the economy have been even greater, since a number of other industries depend on the wine industry. Moldova's National Statistics Bureau estimates that industrial production dropped by 6.9 per cent in 2006 compared to 2005. This was the first time in six years that Moldova had posted such a loss. ${ }^{16}$

\section{What is at stake?}

There are dozens of studies on Transnistrian separatism, often depicted as a 'case of politicised regionalism', or a practice handbook for a 'military plot', or just a 'black hole where secret services, formally belonging to the 'great northern neighbour' do great business', but there is one basic element that relates the separatist Transnistria with other 'statelets', such as Abkhazia and South Ossetia. At the heart of it, a clan has prevailed and usurped the political, military and economic power by dint of Russian arms in a local war, while sixteen years of full isolation under no scrutiny and no public rights and freedoms has led to the installation of an economic-military conclave run by despotic leaders with almost no counterbalancing mechanisms. These 'statelets' have used huge amounts of resources to create their so-called 'state identities', while their rich sponsor, the Russian Federation, has tried to build there a kind

15 Infotag 24 December 2007.

16 Moldova: Counting Losses As Russian Wine Ban Lingers by Ryan Kennedy, 4 April 2007, Radio Free Europe. 
of 'regime with a human face' and has even given birth to some institutions usually linked with 'formal procedural democratic institutions'. Thus, after contemplating the 'reign' of Smirnov as the uncontested leader of PMR (Transnistria) for more than fourteen years, in 2003 Russia finally conceded some internal changes, more or less of an aesthetical nature, in the region. This was expressed through the emergence of Evghenii Shevchuk, leader of the 'Ovnovlen'ye' Party and heavily financed by Sheriff, the most important oligarchic group of the region.

Nevertheless, the public had no power to contest the decisions of the quasi-military conclave, while full control over incomes circulating in the 'off-shore economy', with no clear administrative borders, and the huge military and financial infusions from the patronage exercised by Russia, practically made this regime live through a kind of complex of omnipotence. The origins for such a complex are rooted in the core circumstances that allowed the secession to take place, by the time of the Soviet dissolution and the large amount of disarray in the former Soviet republics.

After 17 years of de facto separation from the rest of the country, Transnistria is the largest of the four breakaway regions of the former USSR, with a population of over half a million, larger than that of Abkhazia, South Ossetia and Nagorno-Karabakh taken together. The breakaway emerged as administrative punishment undertaken by the decaying Soviet centre against Moldovan elites searching for independence in 1991. Fully armoured with ammunition and arms received from the stores of the former $14^{\text {th }}$ Russian Army, separatist guards easily dismantled the constitutional authorities of Moldova on most settlements on the left bank, with the substantive support of the regular military Russian troops. This helped the Transnistrian guards to succeed not only in striking back at the police forces of Moldova but also in winning one of the key military battles in Bender that followed after military hostilities started to escalate in March 1992. Moldova requested UN intervention against the aggression of the Russian Federation but weak international support, and almost no armed forces and resources, led Moldova's first President, Mircea Snegur, to accept direct talks with Russian President, Boris Yeltsin, who promised to make peace over the region.

On 21 July 1992, a Russian-Moldovan ceasefire agreement put an end to military hostilities and, with the installation of Russian peacekeepers, Transnistria freed its hands to create parallel state structures, effectively separate from the constitutional bodies of Moldova. It has to be mentioned that the leaders of the most industrialised part of the RSSM sought a kind of guarantee that they would preserve their independence of action over trade and export. Therefore, fears that right-bank Moldova would move towards unification with Romania was more a stylish political discourse than a real concern. When in 1989 the elites in Chișinău decided to switch from the Cyrillic to the Latin alphabet for their language, in addition to the adoption of the same official flag colours as Romania, some economic and party leaders in Tiraspol found a great excuse to negotiate their separate statute in Moscow, excellently using the whim of the dying Soviet centre to tramp underfoot those republics that challenged Soviet policies and which, like the Baltic states, Ukraine and the Caucasian republics, aspired towards independence. As soon as the Moldovan authorities refused to allow the Soviet centre to organise a referendum in support of the USSR, Moscow decided to use Transnistria as leverage against Moldova's unyielding claims for independence, thus inspiring transfers of armaments and financial resources to create a counterbalancing force in Tiraspol and, on a wave of confrontation with the constitutional au- 
thorities of Moldova during 1991/1992, this led to violent dispute, which escalated into a fully-fledged armed conflict in March-June 1992. ${ }^{17}$

Albeit dominated by Russian speakers, around $40 \%$ of the population in Transnistria have Moldovan - which is virtually identical to Romanian - as a first language. Anything Romanian is viewed with suspicion in Transnistria. Anything coming from Chișinău was regarded with a great dose of suspicion, frustration and mistrust, bitterly critical of the western orientation of the political leaders in Chișinău while remaining loyal to the Russian orientation of Transnistria, the latter being consistently rewarded by Moscow via the granting of substantial privileges to the businesses of the region, allowing infinite concessions for energy and gas consumption while practically substituting local elites with the direct management of Russian intelligence forces. On the right bank of the Dniester, the language dispute has ended, the majority of the population having accepted the idea that there are now two distinct languages Romanian and Moldovan - and that Latin script is the norm for the Romanian language, but in Transnistria this is not the case: its local authorities insist that public education for ethnic Moldovans in their mother tongue is carried out using an artificially-created, Soviet-originated orthography. Schools that performed instruction in the Romanian language using Latin script were forcibly closed by the Tiraspol authorities, in response to which the EU banned the circulation of the Transnistrian leaders in Europe on account of their 'obstructive position' in the settlement process. The school issue has gained notoriety in the international press, but the secessionist leaders claim they reacted in accordance with the laws they have adopted and that no other bodies will block the 'state ideology' that is needed by 'the people of Transnistria'.

The words 'Romania' and 'the west' are continuously demonised by the Transnistrian leaders who constantly link them to the memories of the:

Fascist Romanian occupation, as well as of the dissolution of the Soviet Union, now alive only in the memories of a few nostalgic supporters.

Transnistria touts its own brand of nationalism, while billing itself as the last bastion of Moldovanism (an exotic ideological artefact promoted by Stalin), which it pits righteously against a Romanian-ised, right-bank Moldova. Nevertheless, the ideologues in Tiraspol cannot explain simply why the largest part of Transnistria is still inhabited by Moldovans, living in centuries-old villages along the left- and rightbanks of the Dniester and who have remained loyal to Moldovan statehood; embracing without hesitation the Latin script and their language-identity with other Romanian-speakers; and forming almost $40 \%$ of the whole population of Transnistria.

There are some certainties which exist there. Soviet nostalgia plays well in elections, and equally gives carte blanche in communications with Moscow, particularly when it has repeatedly asserted its legitimate rights to be seen as the 'successor of

17 The breakaway territory's paramilitary forces took over Moldovan public institutions in the area in 1991. Fighting intensified, culminating in a battle on the right bank of the Dniester in June 1992. Up to 700 people were killed in the conflict. A ceasefire was signed in July 1992 and a 10-km de-militarised security zone was established. The settlement was enforced by the Russian 14th Army forces already stationed in Transnistria. 
Tsarist Russia and the USSR all together', when it restored the anthem of the Soviet Union, its military flags, and even the dignities that existed in Soviet times. So, guarding the Tsarist equestrian generals in Tiraspol is not only a tribute to history, it is also a rational calculation of the gains which may be received from a patronaged state with its own vanity and former grandeur. A long decade and a half has passed from the battles that ended in 1992, but the Tiraspol regime still regularly erects memorial complexes symbolising the war against the Moldovan aggressors, as it is to do again in $2008 .{ }^{18}$ Despite fear of unification with Romania being continuously used as the main argument for Transnistrian secessionism, the creation and maintenance of a Transnistrian separate identity was mainly due to the persistence of communist ideology and the so called 'red directors' who opposed any democratic change and reform in Moldova.

For most of the population of Transnistria, the end of the Soviet Union was not emancipation (since there is no single dominant nationality) but deprivation and humiliation. In the face of strong Moldovan nationalism next door, and a rising nationalist Ukraine on the other side, the small but multinational strip of land in the middle saw that its internationalist ideals were about to be trampled and forgotten,

states the newspaper Tiraspol Times in its article 'The legacy of Lenin.' 19

With its declared capital in Tiraspol, ${ }^{20}$ Transnistria became a 'Soviet open air museum' in which all the Soviet-era monuments and names were carefully preserved the Moldovan SSR flag and the coat of arms with the hammer and sickle emblem, as well as old-style communist rhetoric, became the 'business card' of Transnistria. This eastern part of Moldova reminds of a 'Soviet empire in miniature', with the same names on the streets and boulevards, the same feasts and traditions and the memories of the Soviet time conserved.

Its citizens' documents have not been recognised by a single state in the world, so they are used only inside the region. Fortunately for the population of Transnistria, it permits dual citizenship so, besides the self-styled Transnistrian passport, practically every adult person living in Transnistria also has a Moldovan, Russian or Ukrainian passport. According to the Ministry of Reintegration, the number of Transnistrian residents bearing Moldovan documents - foreign-travel passports and domestic identification cards - reached 400000 by 2007.

Since 1992, Transnistria has remained the main headache for the Moldovan state, which has made extensive concessions to bring the breakaway region back into its control but with no practical results. An 'unresolved fragment' of the Soviet Empire, Transnistria has served for a decade and a half as a shipping point for weapons and drugs, and the smuggling of the latter; taking leadership of the "club of unrecognised secessions'; and even supplying other warfare zones with arms and military. Further-

18 'A new Memorial Complex will be erected in Tiraspol in the memory of those who died in the war against aggressors from Chișinău, in 1992' (Olivia Press 19 February 2008).

19 Tiraspol Times 'The legacy of Lenin' 16 July 2006.

20 The city which was the capital of the Moldavian ASSR, an autonomous republic within Ukrainian SSR which existed from 1924 to 1940, prior to the unification of the territory with Moldova. 
more, it fell under the label of transnational organised crime and terrorism many years before the 'war against terrorism' was launched.

Thus, after falling short of concluding any reasonable compromise with the new Communist leaders in Chișinău since 2002, Moscow has staged intensive efforts to consolidate a union of the 'unrecognised entities'. ${ }^{21}$ This aimed on the one hand to provide leverage to counterbalance the emerging GUUAM (Georgia, Ukraine, Uzbekistan, Azerbaijan and Moldova) while, on the other hand, just providing a sort of quasi-recognition statute, strengthening separatist opposition to the governments in Tbilisi, Chișinău and possibly in Kiev. It has to be mentioned that the United States has maintained a visa blacklist of separatist leaders, which the European Union joined in 2003. In February 2008, the ban on one of the Tiraspol leaders was lifted, but most of the leaders of Transnistria still remain on the prohibited lists. At the same time, some countries have announced warnings for their citizens travelling to Transnistria.

The insecurity arising from the continuing situation is deeply resented by ordinary citizens and this has an impact on the functioning of the public authorities in Moldova as well as abroad. In this context, it is not surprising that, in 2007, Moldova was the most unstable European state according to the 'failed states index 2007', as elaborated by US foreign policy. Out of the sixty most vulnerable states in the world, Moldova ranked 48th, scoring 85.7. Only four of the sixty were states located in Europe: Moldova; Belarus (51st); Bosnia and Herzegovina (54th); and Georgia (58th). Even in 2008, Moldova is still cited as one country which has increased political risks. ${ }^{22}$ Economic risks and the reimbursement of debts to international creditors, as well as a poor judiciary and the intervention of politics in economic affairs, lead to Moldova being ranked in the same group as Belarus, Georgia and Armenia.

For over fifteen years, Transnistria has led to Moldova gaining the image as a quasi-sovereign state, unable to control its own territory. For more than a decade, the EU has tacitly acknowledged the leading role of Russia in guiding the never-ending negotiations between the 'parts in conflict', assuming that this could at least preserve the ceasefire agreement while allowing Moldova to recover from its economic decline resulting from the war in 1992 and its unskilled governance.

The EU and NATO has also identified the huge threat stemming from the preservation of the more than 40000 tons of arms which are stockpiled in the region; these are stored in unsecured conditions while the shadow markets of neighbouring Odessa and Nikolayev seem to benefit plenty from the arms smuggling patronage of the separatist regime in Tiraspol. These present huge risks to the domestic reforms in Moldova.

Another damaging by-product of the current situation is that it is impossible for Moldova to emerge as a viable state with 'unwanted' foreign troops on its soil and 550000 of its citizens living in an area which cannot be secured and protected by the appropriate legal authorities. For instance, most of the social and economic policies implemented by the Moldovan government cannot reach the inhabitants of Transnistria since the secession of the region incurred a split in the currency system, as well as in employment opportunities, education and political representation. Moreover, most

21 http://www.strana.ru.

22 Scores calculated by US AON and UK Oxford Analytica, Deca Press Agency, 27 February 2008. 
of the cases of the infringement of human rights and liberties in the region cannot be brought to the European Court of Human Rights in Strasbourg since the regional authorities are not recognised, which implies that they are not liable for the main human rights conventions and corresponding obligations thereunder; the Moldovan government has ratified the Conventions with the reservation that it cannot enforce them on the region which is effectively controlled by the separatist regime.

\section{The EU factor}

With the dual EU and NATO enlargements, the issues of stability and conflict-transformation on the shifting borders of the EU have raised new challenges to the European Commission. Frozen conflicts or, more precisely, the 'unfrozen' core of these unsettled sources of instability, smuggling and insecurity, have raised considerable concerns that the countries affected by territorial splits become a kind of 'group hostage', whereas their prolonged domestic failures reproduce regional insecurities which are clearly magnified by more powerful neighbours. Following Romania's accession last year, the EU shares a border with Moldova. The idea of future integration with the EU is popular, especially among young western-oriented Moldovans. However, its influence is weakened by the tide of European opinion which runs against further enlargement.

Whatever happens to the current settlement plans, the EU will struggle to contain a resurgent Russia. Even so, containment means quite different things to different people and states in Europe, even though they profess to forming a rather post-modern sort of union, ${ }^{23}$ often act in line with their narrow national interests and, therefore, an active use of ESDP (European Security and Defence Policy) resources in the case of the Transnistrian conflict was openly opposed by some states which said that this would make Russia unhappy. Here is where the EU is in an awkward position and this is why a civilian mission, after being proposed to the European Commission, failed as a possible option in 2003, while the active involvement of the EU was possible only after the middle of 2005 when both the Presidents of Ukraine and Moldova requested that the EU monitor and technically support the border guards and customs services, including the part relating to Transnistria. ${ }^{24}$

One area where the EU and Russia should work together is their "common neighbourhood'. This may be difficult: some Russians do not accept that the EU has legitimate interests in the former Soviet republics of Armenia, Azerbaijan, Belarus, Georgia, Moldova and Ukraine. Yet, both the EU and Russia would benefit if these countries became stable, prosperous and well-governed. Fearing more 'colour revolutions' similar to those in Georgia and Ukraine, the Kremlin opposes democratic forces in all these countries on the grounds that they will promote western interests against

23 Ivan Krastev (2008) The crisis of the post-cold war European order: What to do about Russia's newfound taste for confrontation with the West GMF: Brussels Forum Paper series www.gmfus.org.

24 The total extent of the state border of the Republic of Moldova is 1906 kilometres, of which $951 \mathrm{~km}$ border water and $955 \mathrm{~km}$ land. $410 \mathrm{~km}$ of the border with Ukraine coincides with the Transnistrian segment of the frontier which became subject to supervision and control only in March 2006 with the installation of EUBAM, the first EU-sponsored border monitoring mission in the former Soviet space. 
Russia - a policy that risks becoming a self-fulfilling prophecy. Russia also fears encirclement by an expanding NATO. However, the security challenges to a united Europe which are posed by an unsettled Transnistrian conflict are obvious.

The European Commission has moved into Moldova by stating its willingness to assist the country to overcome its overarching problems, but without granting it any 'perspective on integration'. With an Action Plan signed in December 2004, and endorsed on 23 February 2005, Moldova thus became the first country to commit itself to a number of important domestic reforms. The European Neighbourhood Policy, which covers nineteen countries in a ring stretching from Morocco to Belarus, gives zero promise of enlargement and EU hopefuls, such as Moldova and Ukraine, see the policy as a ten-year or more waiting room before any talks on accession can even begin. Moldova wants to break out of the ENP club by converting its current Partnership and Co-operation Agreement with the EU - which expires in mid-2008 - into a new Association Agreement, with a declaration that gives clear commitments as regards future accession; a feat that Ukraine is also trying and failing to accomplish.

The European Parliament has repeatedly stated its support for Moldova's sovereignty and for a unitary statute, calling on Russia unconditionally to withdraw its troops and armaments from the territory of the country. On 26 October 2006, the European Parliament unanimously adopted a Declaration on Moldova, calling on the European Commission to increase its assistance towards supporting Moldova's efforts concerning the settlement of the Transnistrian conflict by preserving its territorial unity within borders which are internationally recognised. What Moldova badly needs is to strengthen the creation both of a functional democracy, based on the rule of law and respect for human rights, and of an economically viable state.

A Moldovan diplomat has recently commented that:

We are not asking for detailed terms but we do want a clear perspective to be built into the commitments.

In comparing his country to EU candidate Macedonia -

We have the same level of development, the territory is about the same size, the population is about the same size,

he acknowledged that Moldova's problem with Transnistria will not make the EU any keener to give accession promises, but said an EU entry horizon 'could help conflict resolution in this region'.

\section{The Russian factor}

At the Organisation for Co-operation and Security in Europe (OSCE) summit in Istanbul in 1999, Russia promised to withdraw its arms caches and troops from the region. However, there has been little progress thus far. The ongoing presence of Russian troops has been a stumbling block to peace talks and the west is clearly concerned about the Soviet-era arsenal on the territory. However, what it also guarantees is the stability of the authoritarian regime in Transnistria and Russia's indirect influence over the whole of Moldova. A pull-out of Russian troops began in 2001 but was halted when Transnistria blocked the dispatch of weapons. Subsequent agree- 
ments to resume have failed to reach fruition. Long-running talks supervised by the OSCE, Russia and Ukraine have yet to yield a political solution, while attempts by Moldova to exert economic pressure on the Transnistrian authorities have failed to produce the desired results. When the deadline for the withdrawal expired on $31 \mathrm{De}-$ cember 2002, the OSCE meekly agreed to extend it for another six months and, after one year, this was extended for another year. Initially, Russian diplomats stated they could not get permission from the separatists to withdraw ammunition from the region, but then Moscow started to argue that its military presence guaranteed peace and stability in the region.

Hopes of a settlement to the Transnistrian conflict had risen after Vladimir Voronin gained power in Chișinău in February 2001. Negotiations were launched but came to a deadlock as soon as the Tiraspol leaders cited that the talks would be hard, stating they knew more about the conflict settlement than Chișinău would like to learn. Nevertheless, Moldova signed a political treaty with Russia in the autumn of 2001, reconfirming officially the indivisibility, integrity and unity of the country, but failed to make any reasonable progresses on a settlement. In 2003, the Russian 'Kozak memorandum' came close to securing a plan under which Transnistria would have enjoyed a wide veto over the decisions of a unified state and kept Russian soldiers in place for several decades. President Voronin pulled out under EU pressure and the vehement protests staged by opposition parties and society in Moldova which contested the idea to make Moldova a confederation, in ignorance of the constitutional arrangements existing in the country. The plan was shelved, causing huge discontent in the Kremlin.

Ukraine subsequently came up with settlement proposals in 2005, presented as the 'Yustchenko plan', but these have also stalled. Russia accepted the expansion of the format of the negotiations after 2003, understanding that the failure of the 'Kozak memorandum' was due to emerging new realities 'on the ground', i.e. a more assertive west, interested in brining peace and stability to its peripheries, but it did not hesitate to ensure that the new format would stagflate to the end.

Subsequently, Russian diplomacy has attempted to play tough on the Kosovo issue, saying that it will multiply it, as soon as the west 'infringes the existing international law system', everywhere across the former Soviet space in which unrecognised states wait for unilateral recognition. ${ }^{25}$ By this it meant that it would respond to any international recognition of Kosovo's declaration of independence by recognising existing de facto states such as Transnistria, South Ossetia and Abkhazia. Officially Russia does not recognise the Tiraspol regime, but it has started invoking the Kosovo precedent, accusing the west of double standards for advocating independence for the nominally Serbian province but opposing the same treatment for Transnistria.

Russia remains the paramount player in the region. Apart from the troops and military equipment which it still maintains in Transnistria, President Putin recently suspended Russia's participation in the 1990 Conventional Forces in Europe Treaty (CFE), on 30 November 2007. ${ }^{26}$ Moscow considers that the original CFE treaty, signed in December 1990 by 16 NATO countries and six Warsaw Pact members, to

25 Deca Press Agency, 5 February 2008.

26 'OSCE's Democracy Agenda Set Back at Year-End Meeting' Eurasia Daily Monitor 4 December 2007. 
be discriminatory and outdated since it does not reflect the dissolution of the Warsaw Pact, the breakup of the Soviet Union or the recent NATO expansion. In a parallel move, Russia imposed crippling restrictions on the ability of the OSCE's Office of Democratic Institutions and Human Rights (ODIHR, the electoral monitoring agency) to monitor Russia's 2 December parliamentary elections, thus forcing ODIHR to desist. In the run-up to the year-end meeting, an emergent bloc of seven post-Soviet states under Russian leadership submitted further proposals that would disable the OSCE's role in democracy-promotion. Russia is angry over the non-ratification of the treaty by NATO countries and western insistence on Russian troops withdrawing from Moldova and Georgia. This makes some leading European analysts to say that the Soviet Union was easier to deal with than today's Russia, as a senior French diplomat has commented:

Sometimes the Soviets were difficult, but you knew they were being obstructive in order to achieve an objective. Now Russia seeks to block the west systematically on every subject, apparently without a purpose. ${ }^{27}$

Russia blocked a UN Security Council resolution that would authorise independence for Kosovo under EU tutelage. It is thwarting US and EU efforts to impose more UN sanctions on Iran. It says that, if the US proceeds with plans to install missile defence systems in Poland and the Czech Republic, it will target missiles on European cities. It has blockaded Georgia. Its ban on imports of Polish meat has led the EU to walk away from talks on a Partnership and Co-operation Agreement.

Speaking on the fifteenth anniversary of the ceasefire, Mircea Snegur, the first Moldovan President following independence, blamed the conflict squarely on Russia. Snegur commented:

In fact, at that time we were at war directly with Russia. What could we do, faced with a monster? By signing this agreement we proved to the whole world that the instigator and direct participant in this war was the Russian Federation... I even wonder why they signed the document, which amounts to a recognition of their involvement.

But Transnistrian leader Igor Smirnov, in his seventeenth year in power, rejects western calls for Russian troops to leave:

Against the background of failures of western peacekeepers in the Balkans, Iraq, Afghanistan and other 'hot spots', they offer to replace Russian peacekeepers with an international contingent... If those who adhere to that idea force us, they will get new bloodshed.

\section{New geographic shifts}

It was apparent, following the general election in 2005, that Moldova changed westwards and this provided the grounds for the adoption of some very important laws, i.e. the Law on the special statute of Transnistria, the Law on the basic principles and norms for a settlement, the Law on social rights and benefits to the population of the

27 Quoted after Charles Grant (2007) 'A new deal with Russia?’ Prospect Magazine November. 
eastern rayons, etc. With the installation of the European Union Border Assistance Mission in March 2005, the Moldovan authorities opened the door to Transnistrian businesses to trade on the European market, after legalising their business in Chișinău. Following the adoption of the Action Plan with the EU, Moldova signed, first, a GSP+ agreement with the EU and then, in December 2007, an Asymmetric Trade Preference Agreement. By March 2008, over 450 large and medium sized enterprises have been legalised and are operational, with more than $€ 800 \mathrm{~m}$ of exports to the EU countries.

President Voronin initiated new talks with Russia in autumn 2006. The US and the European Union which, like Russia, have long been involved in maintaining stability in Moldova, were taken by surprise. When the contacts were made public, Moldovan officials insisted they had not intended to keep the west in the dark or to negotiate outside an agreed multilateral framework. Nevertheless, Voronin has kept pressing Russia for a deal, most recently at a meeting in St. Petersburg with President Vladimir Putin. However, Moscow has so far kept quiet about its intentions. Moreover, despite accepting to speak with Voronin, after the 2003 Kozak memorandum setback, the Kremlin fuelled hopes in Tiraspol on possible recognition in response to the emerging situation with regard to Kosovan independence. Thus, on 10 September 2006, it sponsored a new referendum in Transnistria on the subject of 'joining Russia and departing Moldova', in which 97 per cent of Transnistrians voted for independence. One year later, presidents Putin and Voronin tried to show peace and friendship in agreeing that a 'package agreement' had been reached and that the conflict had no other reason to stay unresolved. ${ }^{28}$

In keeping quiet ahead of the time about the 'bargain' he might be discussing in Moscow, Voronin overstretched his own abilities to deliver a solution on Transnistria which would be acceptable to the Russians. The Transnistrian issue is not carried high on the agenda of the population, ${ }^{29}$ but Voronin wants a settlement to boost his flagging popularity. With this in mind, he has tried to show that settlement is now possible and inevitable. ${ }^{30}$ However, in Tiraspol, the political leaders reject any deal that would damage their power base. Igor Smirnov, the ageing President loyal to the Kremlin is under growing pressure from Evghenii Shevchuk, the young Speaker of parliament, who wants to maintain the region's status quo. It seems that vested interests around the secessionist enclave have deep roots and, even if Smirnov is eventually pushed out of office, there is little chance of a rapid policy change. Tiraspol dropped out of multilateral settlement talks in 2005 when the EU border mission started.

One western official says that, for Moscow, the debate comes down to whether it is worth swapping 90-100 per cent influence over Tiraspol for a smaller say in a reu-

28 Elections in Transnistria and Moldovan Paradoxes www.azi.md 7 December 2007.

29 The last Public Opinion Barometer carried out by IPP in November 2007, demonstrates that the settlement of the Transnistrian issue is placed only seventh on the list of the most important problems perceived by Moldovan society.

30 Moldovan President Vladimir Voronin's speech at the summing-Up news conference Moldpres 19 December 2007: 'We have changed the format of relations with Russia and the countries of the CIS. Now these relations are not merely pragmatic, they have become true partnership relations.' 
nited country. Under the tentative proposals which eventually emerged, Moldova would guarantee its neutrality and legalise Transnistria's privatisations, including those involving Russian companies. There would be new country-wide elections and Tiraspol would be given 18 or 19 seats in the 101-member Moldovan parliament (compared to the 14 it would get on the basis of population), plus guaranteed ministerial posts. Vasile Shova, Moldova's re-integration minister, says that Russian troops would pull out before the proposed elections. Others who have seen the plans say they would be allowed to stay longer, raising fears that they might never leave. Shova says the plan:

Accommodates Russian interests to the extent that they don't contradict Moldovan interests.

Iurie Rosca, the leader of the Christian Democrat party, says the proposals are 'illegal and dangerous' and could block Moldova's EU integration.

It is thought that Russia is ready to guarantee the re-unification of Moldova in exchange for a refusal to join NATO. The necessary documents could be signed in the near future. In an interview with a $\mathrm{b}$ correspondent, Voronin provided some details about the way in which Moscow and Chișinău would implement an 'anti-Kosovo' scenario in Transnistria. In addition, Voronin let it be understood that Moldova could withdraw from GUUAM, a move that attracted sharp criticism in Kiev and in the other capitals.

Nevertheless, Moscow contradicted some parts of Voronin's statements on the resolution of the Transnistrian issue. First of all, the Russian Ministry of Foreign Affairs stated its unequivocal support for the principle of parity between the parts, irrespective of Moldova being a constitutionally unitary state, internationally recognised, whereas the Transnistrian statelet is not recognised at all. At the same time, other officials of the Russian Duma referenced in their statements the implementation of the Primakov plan of 1997, which baptised the term 'unified state', created on the basis of agreement between two entities with equal shares of power. The Russian Duma abstained from declaring its direct support for independence of secessionist enclaves in March-April 2008, immediately after the recognition of Kosovo, but signals were directed to Transnistria to accept a settlement with Moldova.

Nevertheless, time seems to be running out for Voronin's initiative, with tensions between Russia and the west escalating amidst the concentration of the Kremlin on its March presidential elections. Marian Lupu, Speaker of the Moldovan parliament, says:

The general atmosphere is very bad, so I don't see a big chance of a settlement.

\section{Conclusion}

It remains heavily dependent on Russian political and economic support, and will usually take into account Russian perspectives, but Transnistria is a political entity with its own interests that it has the ability to advance through lobbying, economic opportunism, political posturing and creative negotiating. The parallel economy remains its most important bargaining tool. When their interests align, the regime is more than happy to provide Russia with leverage it can use against the Moldovan government. 
Certainly, the current situation in Transnistria differs dramatically from the one in the 1990s. Transnistria is becoming an increasingly depopulated zone and the false unanimity common to all totalitarian regimes is being replaced with tough competition between different clans and different competitors, despite sharing the same lifelong aim of preserving the status quo for a regime that supplies excellent ways of making easy money, under the shelter of a resurgent Russia, itself still unclear whether it is a declining or an emerging power.

The previous failures of attempts to settle the conflict demonstrate that solutions cannot be found in bilateral talks which provide unilateral benefits to the mediating countries, and that any possible solution needs to consider the prerequisites for a democratic solution found for and through democratic leverages, internationally assessed and conforming with OSCE and Council of Europe political standards. This requires not only talks, but also confidence and democratic co-operation without ambiguities. 